\title{
Interactions between waves, bank erosion and emergent vegetation: an experimental study in a wave tank
}

\author{
Hugo Coops ${ }^{a, *}$, Noël Geilen ${ }^{a}$, Henk J. Verheij ${ }^{b}$, René Boeters ${ }^{c}$, \\ Gerard van der Velde ${ }^{\mathrm{d}}$ \\ anstitute for Inland Water Management and Waste Water Treatment (RIZA), P.O. Box 17, 8200 AA Lelystad, \\ The Netherlands \\ ${ }^{b}$ Delf Hydraulics, P.O. Box 152,8300 AD Emmeloord, The Netherlands \\ ${ }^{c}$ Road and Hydraulics Engineering Division, P.O. Box 5044, 2600 GA Delf, The Netherlands \\ 'Department of Ecology, Laboratory of Aquatic Ecology, University of Nijmegen, Toernooiveld, 6525 ED \\ Nijmegen, The Netherlands
}

Accepted 18 January 1996

\begin{abstract}
Emergent vegetation development, wave extinction and soil erosion are strongly interrelated processes in exposed riparian zones. The above-ground parts of the vegetation reduce wave energy, while the below-ground parts strengthen the soil. On the other hand, vegetation development may be restricted as a result of wave stress. Interactions between waves, soil erosion, and emergent vegetation were studied during three consecutive years. Two helophyte species, Phragmites australis (Cav.) Trin. ex Steudel and Scirpus lacustris L., were planted in separate bank sections on two types of sediment, sand and silty sand, in a wave tank. Regular waves were transmitted through $4 \mathrm{~m}$ wide bank sections with and without helophytes growing on a horizontal part. Bank profiles, wave transmission patterns and vegetation parameters were measured after exposure to waves with a height of $10 \mathrm{~cm}$ (Year 1) and $23 \mathrm{~cm}$ (Years 2 and 3). Both $10 \mathrm{~cm}$ and 23 $\mathrm{cm}$ waves affected bank profiles. Erosion of the banks occurred due to downslope transport of sediment. Soil erosion patterns closely reflected the patterns of standing waves over the horizontal part of the bank. Emergent vegetation influenced the erosive impact of waves by both sediment reinforcement and wave attenuation. A smaller amount of net erosion was measured in the wave-exposed sections covered by vegetation than in the unplanted sections. The stands of Scirpus lacustris were damaged due to uprooting of rhizome parts by $23 \mathrm{~cm}$ waves, followed by increased erosion of the soil. No damage occurred to the Phragmites australis stands. The greatest
\end{abstract}

\footnotetext{
- Corresponding author.
} 
wave attenuation (measured as relative wave height reduction) was measured in the fully developed vegetation in August of each year in both types of vegetation.

Keywords: Bank protection; Erosion; Helophytes; Phragmites; Scirpus; Waves

\section{Introduction}

Emergent vegetation may have an important function in preventing bank erosion due to wave attack. Energy is dissipated while waves are transmitted through the vegetation. Moreover, the bank slope may be stabilized by the framework of roots and rhizomes reinforcing the soil. On the other hand, vegetation development may be affected by wave attack and erosion of the sediment. The potential role of emergent vegetation in preventing erosion of banks has been described in various studies (Sukopp et al., 1975; Bache and Macaskill, 1981; Bonham, 1983; Thorne, 1990). Emergent vegetation has been approached as a factor contributing to bank stability, in particular by reduction of wave energy during the transmission of waves through the vegetation. However, no attempts have been made to describe interactions between the wave regime, erosion processes and emergent vegetation development on banks. Wave exposure has been found to be a structuring process for helophyte vegetation due to influences on the plants themselves as well as on the substrate (Weisner, 1987; Coops et al., 1991). The impact of waves on bank stability in relation to emergent plant development was subject of the present study. The possible relationship between the interacting features is schematically drawn in Fig. 1.

Earlier field experiments have demonstrated the effects of wave exposure on the response of helophyte species to substrate type and water depth (Coops et al., 1991; Coops et al., 1994). An opportunity to study simultaneously the processes of plant development, wave extinction and erosion was provided by a 3-year experiment in a wave tank. Interactions between waves and emergent plants, represented by two species that often dominate the reedbelt zone, Phragmites australis (Cav.) Trin. ex Steudel and Scirpus lacustris L., were studied.

The present paper focuses on two questions: (1) what are the effects of vegetation on waves; and (2) how does wave action affect vegetation performance?

\section{Materials and methods}

\subsection{Experimental design}

Experiments were carried out in a basin connected to a wave generator at Delft Hydraulics in De Voorst (The Netherlands). The waves approached an outdoor bank which was subdivided into 14 separate sections (twelve of $2.55 \mathrm{~m}$ width, two of $0.90 \mathrm{~m}$ width), separated by stone walls (Fig. 2). The sections were alternatingly filled with two types of sediment (sand, median grain size $0.270 \mathrm{~mm}, 2.3 \%$ lutum; and silty sand, median grain size $0.160 \mathrm{~mm}, 3.7 \%$ lutum). Each section consisted of a lower slope (1.75 


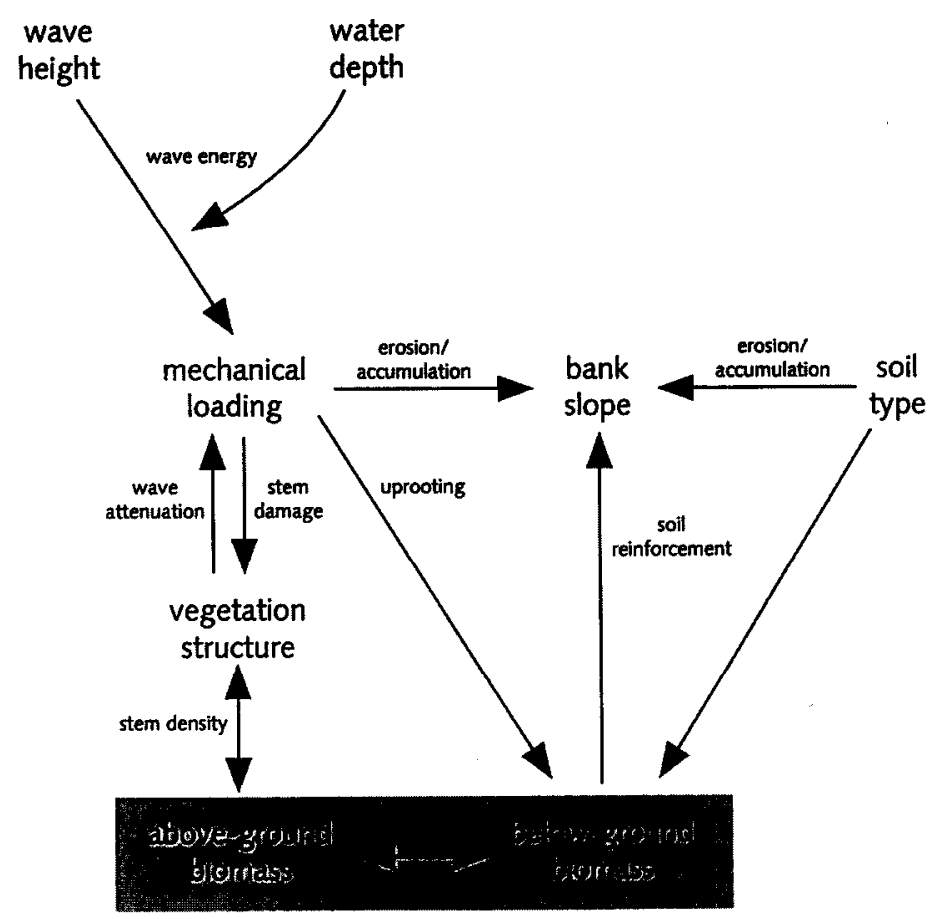

Fig. 1. Schematic representation of the impact of wave action on emergent plant growth and bank profile.

$\left.\mathrm{m}, 25^{\circ}\right)$, a flat part $(4 \mathrm{~m})$ and an upper slope $\left(1.5 \mathrm{~m}, 45^{\circ}\right)$. The water level was fixed at $50 \mathrm{~cm}$ above the flat part of each section, but was lowered to $\pm 0 \mathrm{~cm}$ for short periods during vegetation measurements.

Rhizome parts of the helophyte species $P$. australis (mean dry weight of the rhizome part $4.57 \pm 2.58 \mathrm{~g}$ ) were planted on the flat parts of six of the bank sections. Six other sections were planted with $S$. lacustris (mean dry weight of the rhizome part $19.99 \pm 7.04$ g). The two species were planted to develop monospecific stands in separate bank sections, while two sections were left unplanted. Both species were planted in March 1990 , at a density of rhizome parts of eight to ten parts per square metre. Four sections were situated beside the basin in which waves were generated, and were not subjected to waves. Vegetation development continued undisturbed until August 1991, when a programme of wave treatments began.

Between August 1991 and May 1992, $10 \mathrm{~cm}$ high waves were generated during $24 \mathrm{~h}$ every 4 weeks. As the effects were less than expected, wave heights were increased to $23 \mathrm{~cm}$ in the period June 1992-October 1993. The wave period was $1.9 \mathrm{~s}$, and wave length was $4.80 \mathrm{~m}$. These parameters can be regarded as roughly representative of waves in channels with intensive shipping traffic (Huber and Weiss, 1986). Four sections only received half this number of waves, using an adjustable wave absorber. The above-ground vegetation was removed by mowing in October 1993, whereafter additional measurements could be made of wave patterns over the slopes without the damping effect of the vegetation. 


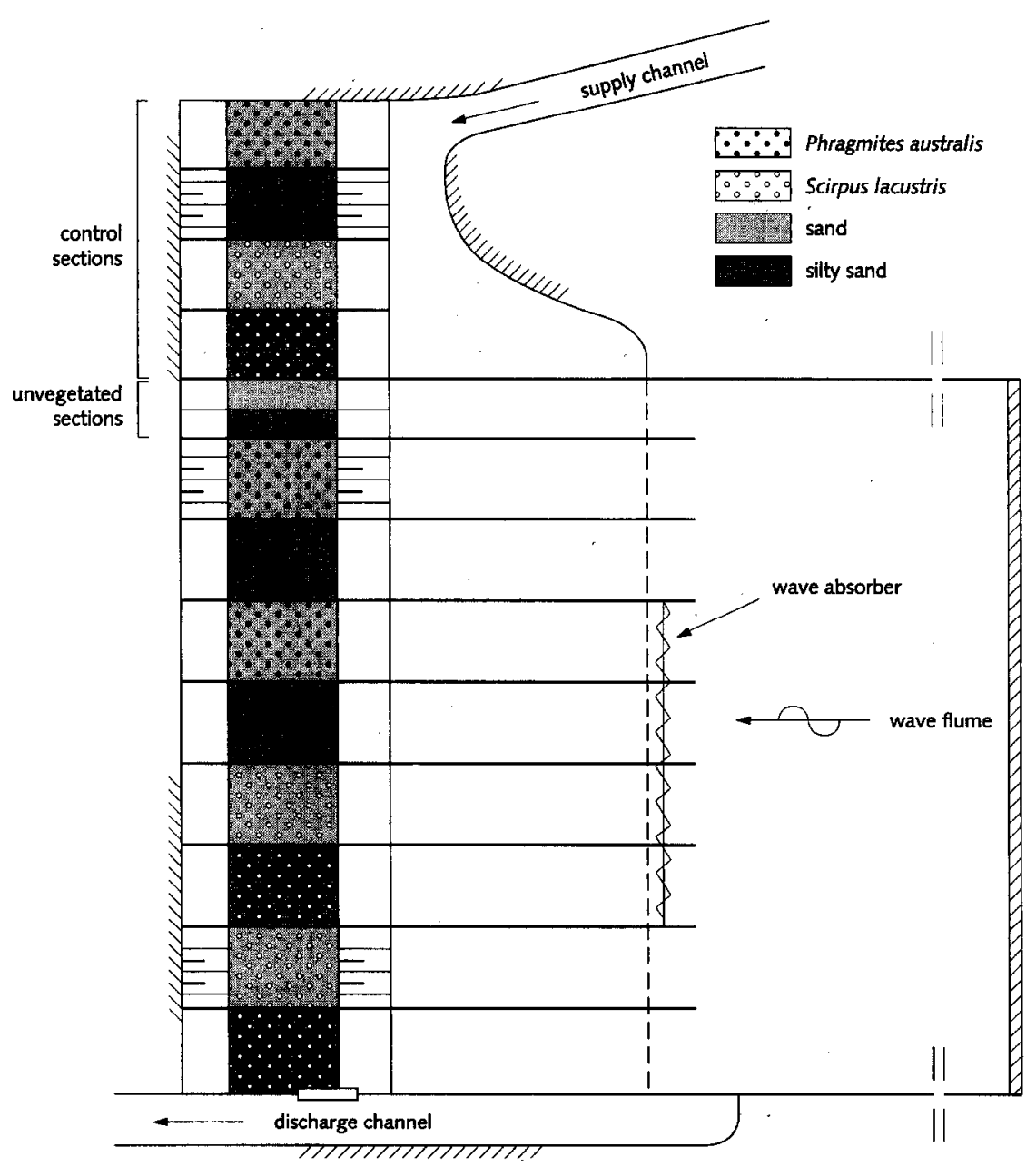

cross-section

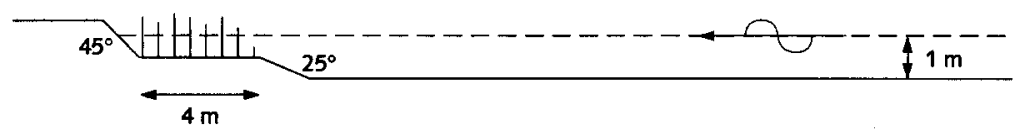

Fig. 2. Experimental setup of the wave tank showing the bank sections. Below: longitudinal cross section of the wave tank.

\subsection{Wave extinction}

Wave heights were measured in transects over the entire slope at $1 \mathrm{~m}$ intervals in August 1991 (Week 35) and February 1992 (Week 7), and at $10 \mathrm{~cm}$ intervals in August 1992 (Week 34), February 1993 (week 10), August 1993 (Week 35), and October 1993 (Week 39). Wave heights were recorded using a capacitive rod (precision $0.003 \mathrm{~m}$ ) 
hanging from a bridge that could be moved over all sections. Average wave height reductions per transect relative to the incoming wave height were calculated. Treatments were compared by calculating the relative wave height reduction (RHR) as follows:

$$
\mathrm{RHR}=\frac{\text { wave extinction in sections with vegetation }}{\text { wave extinction in sections without vegetation }}=\frac{H_{\mathrm{in}}^{*}}{H_{\mathrm{out}}^{*}} \cdot \frac{H_{\mathrm{out}}^{0}}{H_{\mathrm{in}}^{0}}
$$

in which $H_{\text {in }}^{*}=$ wave height $(\mathrm{m})$ in vegetated sections, $H_{\text {out }}^{*}=$ wave height $(\mathrm{m})$ in front of vegetation, $H_{\text {out }}^{0}=$ wave height $(\mathrm{m})$ in front of unvegetated berms, $H_{\text {in }}^{0}=$ wave height $(\mathrm{m})$ in unvegetated sections. RHR values $<1$ indicate wave damping by the vegetation; due to the varying degrees of erosion, the RHR values measured after the mowing of the vegetation in October 1993 may best represent absence of wave extinction by vegetation.

RHR values were tested against $R H R=1$ using a $t$-test. In addition, the maximum wave heights measured inside the vegetation zone were compared among the species using a $t$-test at $P<0.05$. Water-flow velocities $\left(u_{\max }, \mathrm{m} \mathrm{s}^{-1}\right)$ were measured $5 \mathrm{~cm}$ above the soil level at two locations within the flat part of each section, using a two-dimensional electromagnetic flow meter (max. inaccuracy $0.01 \mathrm{~m} \mathrm{~s}^{-1}$ ).

\subsection{Soil surface and rooting patterns}

The topography of each bank section was determined at the sampling intervals by measuring the vertical distance from the measuring bridge to the soil surface over three transects per section at horizontal distances of $0.25 \mathrm{~m}$, using a simple recording pole (precision $0.005 \mathrm{~m}$ ).

The amount of net erosion relative to the original surface area was determined in August 1992 (following the period with $10 \mathrm{~cm}$ waves) and August 1993 (following the period with $23 \mathrm{~cm}$ waves). For each transect net erosion was determined by integrating the sediment profile reductions measured, and expressed as $\mathrm{m}^{3}$ sediment eroded per $\mathrm{m}$ bank width.

To assess root distributions in the soil, six cores of the top $40 \mathrm{~cm}$ of the soil including roots were cut at the end of the experiment from two sections per species, using a $\phi 5.6$ $\mathrm{cm}$ core with a sharp stainless steel edge. The soil segment was divided into $10 \mathrm{~cm}$ depth intervals, and root biomasses ( $\mathrm{g}$ dry weight at $105^{\circ} \mathrm{C}$ ) were determined for each depth interval. The mean percentage of below-ground biomass in each depth interval was calculated. The difference in median root-biomass depth between the two species was tested using a $t$-test. In addition, the specific density of rhizomes was determined by relating the dry weight of rhizome parts to their volume.

\subsection{Vegetation performance}

Standing crops of the vegetation were determined in June 1991 (Week 25), August 1991 (Week 34), June 1992 (Week 21), August 1992 (Week 31), June 1993 (Week 23) and August 1993 (Week 36). At each sampling date, individual stem heights were determined in each of three $0.5 \mathrm{~m}^{2}$ rectangular plots on the flat part of each section. 


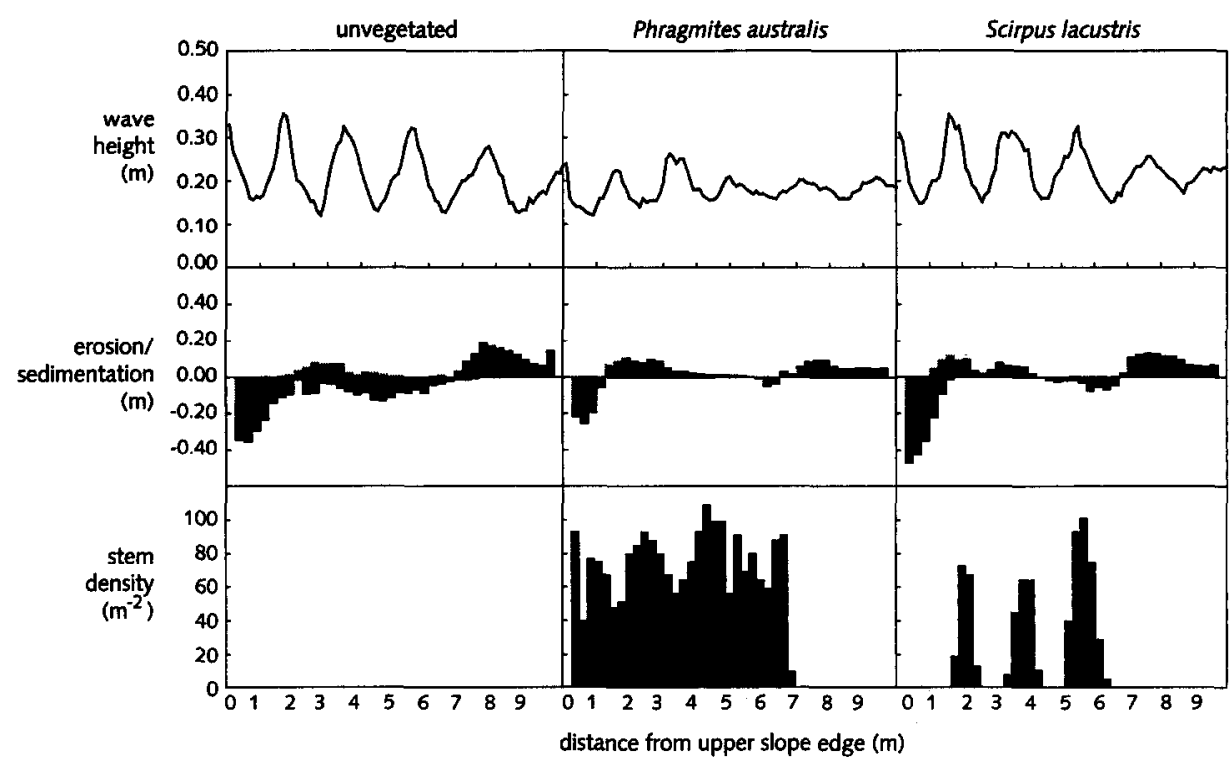

Fig. 3. Average profiles of (a) wave reflection pattem (wave height (m)), (b) erosion $(-)$ / sedimentation $(+)$ (m) (shaded = after $10 \mathrm{~cm}$ waves), (c) stem density $\left(\mathrm{m}^{-2}\right)$ in the unplanted control sections, and the sections planted with Phragmites australis, and those planted with Scirpus lacustris, on sandy soil, in August 1993. Waves approach from the right-hand side.

Individual stem biomass was determined (dry weight after $48 \mathrm{~h}$ at $105^{\circ} \mathrm{C}$ ) of a sample of 20 individual stems from each planted section. For both species, a regression equation between stem length and biomass was derived at each sampling date; above-ground vegetation biomass of each plot could be calculated as the sum of all individual stem biomasses in that plot.

Final stem densities across bank transects were determined in three rows of 0.25 $\mathrm{m} \times 0.50 \mathrm{~m}$ plots in each section, by counting stem bases on photographs taken vertically from the measuring bridge after the vegetation had been mown.

The downslope vegetative expansion was determined by measuring for each section the maximum distance of culms that had been generated out of the waterside planting edge into the lower slope.

\section{Results}

\subsection{Wave heights}

Reflection of the waves (mainly by the slope behind the vegetation) led to standing waves. The typical pattern of waves in August $1993\left(H_{0}=23 \mathrm{~cm}\right)$ is presented in Fig. 3 . Antinodes were high in the sections without vegetation $(0.34 \pm 0.02 \mathrm{~m})$ and in the $S$. lacustris vegetation $(0.33 \pm 0.02 \mathrm{~m})$, while the antinodes in the wave pattern were significantly $(P<0.05)$ lower in the $P$. australis vegetation $(0.23 \pm 0.03 \mathrm{~m})$. 


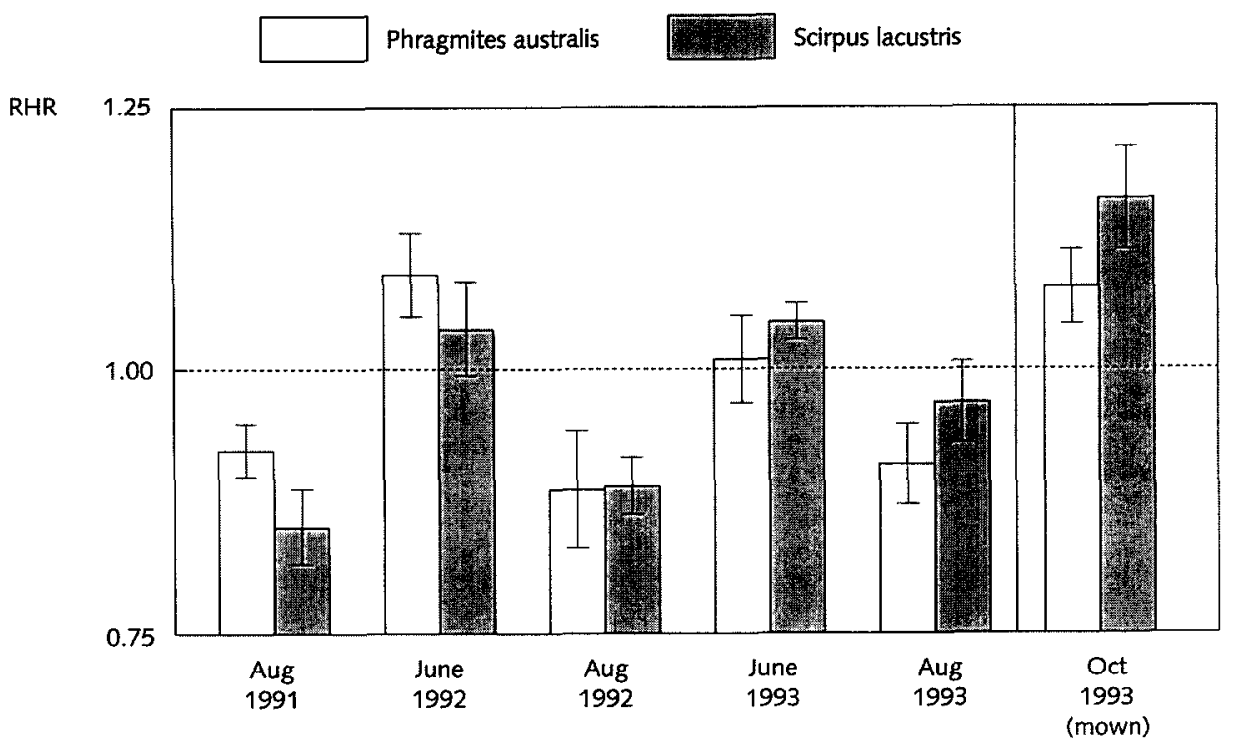

Fig. 4. Relative wave height reduction (RHR, for definition see text) in bank sections with Phragmites australis and Scirpus lacustris at the sampling dates.

Average wave heights over the flat parts of the bank sections ranged from $71 \%$ to $129 \%$ of the height of incoming waves for the planted sections, and between $80 \%$ and $137 \%$ for the sections without vegetation, which have resulted from the combined effects of shoaling, reflection, and attenuation of waves. However, the wave height reductions over the vegetated slopes relative to those in the unplanted sections (RHR) showed that there was a pronounced effect of the presence of vegetation on wave transmission (Fig. 4). In the measurements conducted in August, when the aboveground parts of the vegetation were fully developed, RHR was significantly $<1(P<0.05)$ for both types of vegetation, except for $S$. lacustris in 1993. In contrast, RHR was $>1$ in February (except for $P$. australis in 1993) and in October 1993, after the vegetation had been mown. RHR was significantly higher for S. lacustris in August 1993 compared to the measurements in August 1991 and 1992, which was consistent with the greater damage done by wave attack to this vegetation type.

Initially, the maximum flow velocities in the sections without vegetative cover were higher than in those planted with helophytes, but this difference disappeared due to changes in the bank profiles (Table 1).

\subsection{Soil profile and rooting patterns}

The greatest effects of wave attack on the soil profiles in the exposed bank sections were observed to occur within the first few days after starting the $10 \mathrm{~cm}$ and $23 \mathrm{~cm}$ wave height treatments. Soil erosion was apparent over the entire slope of the wave-exposed bank sections. Sediment deriving from erosion at the upper slopes was deposited 
Table 1

Maximum flow velocities $5 \mathrm{~cm}$ above soil level in the sections in the wave tank with and without vegetative cover

\begin{tabular}{llll}
\hline Maximum flow velocities (m s & & \\
& August 1991 & August 1992 & August 1993 \\
\cline { 2 - 4 } Wave height $(\mathrm{cm})$ & 10 & 23 & 23 \\
\hline Without vegetation & $0.205 \pm 0.085^{\mathrm{a}}$ & $0.533 \pm 0.137^{\mathrm{a}}$ & $0.371 \pm 0.048^{\mathrm{b}}$ \\
Phragmites australis & $0.130 \pm 0.029^{\mathrm{b}}$ & $0.361 \pm 0.079^{\mathrm{b}}$ & $0.372 \pm 0.105^{\mathrm{b}}$ \\
Scirpus lacustris & $0.144 \pm 0.056^{\mathrm{b}}$ & $0.478 \pm 0.089^{\mathrm{a}}$ & $0.475 \pm 0.104^{\mathrm{a}}$ \\
\hline
\end{tabular}

Wave tank with cover by Phragmites australis and Scirpus lacustris $(n=16)$ and without vegetative cover $(n=8)$. Mean velocities indicated by different symbols are significantly different within a sampling period ( $t$-test, $P<0.05$ ).

on the adjoining flat part, while sediment from the horizontal part near the lower slope was transported to the deeper part of the flume (Fig. 3). The largest sediment transport occurred over the unvegetated sections, resulting in a levelling of the slope; in these sections, three erosion areas could be detected over the bank profile, relating to the antinodes in the wave reflection pattern.

The presence of vegetation appeared to have an effect on the amount of eroded soil material in the wave-exposed sections. Net erosion in sections with silty sand $(0.14 \pm$ $\left.0.03 \mathrm{~m}^{3} \mathrm{~m}^{-1}\right)$ was about the same as in the sandy sections $\left(0.12 \pm 0.03 \mathrm{~m}^{3} \mathrm{~m}^{-1}\right)$. Net erosion amounted to $0.75 \pm 0.01 \mathrm{~m}^{3} \mathrm{~m}^{-1}$ in the unvegetated sections; significantly less net erosion $\left(0.50 \pm 0.11 \mathrm{~m}^{3} \mathrm{~m}^{-1}\right)$ occurred in the sections planted with $S$. lacustris. The net erosion in $P$. australis $\left(0.21 \pm 0.06 \mathrm{~m}^{3} \mathrm{~m}^{-1}\right)$ was signicantly lower than in $S$. lacustris.

After 3.5 years growth, $S$. lacustris had produced a greater below-ground biomass $\left(3496 \pm 2867 \mathrm{~g} \mathrm{DW} \mathrm{m}^{-2}\right)$ than $P$. australis $\left(1644 \pm 739 \mathrm{~g} \mathrm{DW} \mathrm{m}^{-2}\right)$. While the

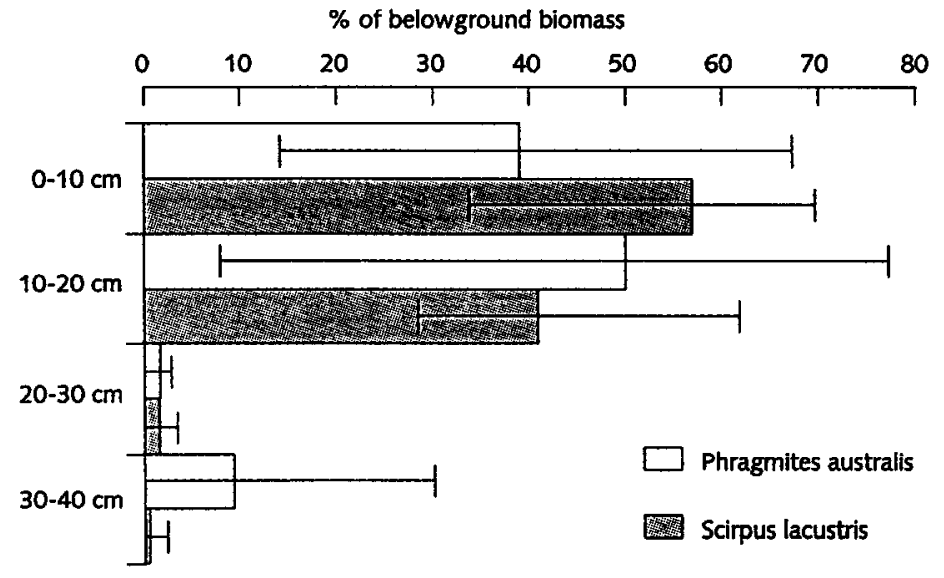

Fig. 5. Distribution of belowground parts (roots and hizomes) of Phragmites australis and Scirpus lacustris as a percentage of the dry weight biomass ( \pm 2 S.E., after angular transformation) over soil depth layers. 
Table 2

Regression equations for the relationships between stem height and stem biomass in $P$. australis and $S$. lacustris, used to determine above-ground biomass

\begin{tabular}{lll}
\hline $\begin{array}{l}\text { P. australis } \\
\text { Before August } 1993\end{array}$ & $\ln W=2.13 \ln L-9.49$ & $R^{2}=0.82, n=603$ \\
August 1993 & $\ln W=1.59 \ln L-6.23$ & $R^{2}=0.75, n=121$ \\
S. lacustris & $\ln W=1.78 \ln L-8.32$ & $R^{2}=0.82, n=432$ \\
Before August 1993 & $\ln W=0.75 \ln L-2.59$ & $R^{2}=0.40, n=98$ \\
August 1993 &
\end{tabular}

$L$, stem height $(\mathrm{cm}) ; W$, stem biomass ( $\mathrm{g} \mathrm{DW})$.

specific density of below-ground parts of the latter was lower $\left(0.91 .10^{-6} \mathrm{~g} \mathrm{DW} \mathrm{m}^{-3}\right.$ for $P$. australis versus $1.15 .10^{-6} \mathrm{~g} \mathrm{DW} \mathrm{m}^{-3}$ for $S$. lacustris), the total below-ground volume was smaller as well. It was observed that $P$. australis roots were more finely distributed in the soil than $S$. lacustris roots. The root system of $S$. lacustris tended to be more concentrated in the upper soil layers than that of $P$. australis (Fig. 5), but the difference between the median rooting depths $(S$. lacustris $9.4 \pm 2.9 \mathrm{~cm}, P$. australis $16.4 \pm 9.8 \mathrm{~cm}$ ) was not significant ( $t$-test, $P=0.08)$.

\subsection{Vegetation development}

The relationship between individual stem height and stem biomass was fairly constant over time, except for the last sampling date. Therefore, all data except those for the last harvest were pooled in the equations (Table 2). The equations were applied in a non-destructive biomass determination within each of the quadrats, based on measured stem lengths.

During the experiment, $P$. australis showed a higher above-ground biomass than $S$. lacustris. In August 1993, biomass was higher in the control sections than in the wave exposed sections (Table 3).

Rhizome expansion over the lower slope occurred in the sections planted with $P$. australis. The maximum distance of rhizome expansion from the planting edge was $2.7 \pm 0.4 \mathrm{~m}$ in the wave-exposed sections and $2.4 \pm 0.3 \mathrm{~m}$ in the reference sections. $S$.

Table 3

Above-ground biomass of the vegetation on the flat part of the sections in August 1993

\begin{tabular}{lll}
\hline $\begin{array}{l}\text { Above-ground biomass (g dry weight } \mathrm{m}^{-2} \pm \mathrm{s.d} \text { ) } \\
P . \text { australis }\end{array}$ & S. lacustris \\
\hline $\begin{array}{l}\text { Waves } \\
\text { Sand } \\
\text { Silty sand }\end{array}$ & $235.9 \pm 84.3^{\mathrm{b}}$ & $169.2 \pm 88.8^{\mathrm{b}}$ \\
Control & $399.7 \pm 135.1^{\mathrm{a}}$ & $248.5 \pm 77.0^{\mathrm{b}}$ \\
Sand & & \\
Silty sand & $401.1 \pm 106.4^{\mathrm{a}, \mathrm{b}}$ & $294.9 \pm 145.8^{\mathrm{a}, \mathrm{b}}$ \\
\hline
\end{tabular}

Different symbols indicate significantly different ( $t$-test, $P<0.05$ ) biomasses within the species. 
lacustris expansion was not found in the control sections, while the wave-exposed sections showed a retreat of the vegetation due to erosion of the planting edge at the lower slope $(-1.0 \pm 0.1 \mathrm{~m})$.

\section{Discussion and conclusions}

Erosion of bank profiles is clearly related to the distribution of the wave energy over the slope. The pattern of (standing) wave heights, as shown in Fig. 3, may be interpreted in terms of wave energy, as wave energy is quadratically related to wave height (Denny, 1988). Bank morphology, organic matter accumulation and vegetation density were affected by the pattern of standing waves as well. While even $10 \mathrm{~cm}$ waves were sufficient to cause considerable alterations to the slopes in the unplanted sections of the wave tank, such waves did not greatly affect slopes under vegetation cover. By contrast, $23 \mathrm{~cm}$ waves appeared to be able to wash out $S$. lacustris, but not $P$. australis. Wave characteristics, such as height and period, may vary considerably, depending on the type and speed of passing ships. In a study of the erosion caused by boat-generated waves, Nanson et al. (1994) found severe erosion of unvegetated river banks at wave heights exceeding $30 \mathrm{~cm}$, caused by the passage of recreation vessels.

The critical wave height leading to soil surface wash out is related to the depth of the wave-mixed zone (Spence, 1982). In addition to bank depth and morphology, sediment composition is a major factor affecting the spatial distribution of erosion (Hooke, 1979). Erosion of soil occurs when the actual shear stress under the wave, sediment and depth conditions present, exceeds the critical shear stress. Sand particles may be eroded at current velocities of $0.2 \mathrm{~m} \mathrm{~s}^{-1}$ (Hjulström, 1935; Håkanson and Jansson, 1983), while unconsolidated silt is eroded at even lower current velocities. Accordingly, sand and silty sand in the wave tank were transported by waves of both $10 \mathrm{~cm}$ and $23 \mathrm{~cm}$. Initially, average water current velocities were lower inside than outside the vegetated bank sections, as a result of increased roughness. However, erosion of the slopes meant that the water depth increased over the unvegetated sections in the course of the experiment, resulting in lower current velocities than would have occurred at the original profile of the sections.

The presence of vegetation cover had a strong effect in reducing erosion. This was most pronounced in the case of $P$. australis. High stem densities increase the retention of waterborne sand (Knutson, 1988), so the entrapment of eroded sediment within the vegetation contributed to the much smaller rates of erosion in the planted sections. Gleason et al. (1979) found that waves transported sand into the vegetation, resulting in accumulation near the vegetation edge and the creation of steeper slopes. Seasonal patterns of sediment accretion and erosion in relation to vegetation development and storm events have been demonstrated in saltmarsh edges (Ranwell, 1964; Giroux and Bédard, 1987). This experiment showed that sediment deriving from the upper slopes of the bank was trapped on the flat part of the sections if vegetation was present, and that the sediment was transported further downslope when vegetation was absent.

Apart from the transport of sediment particles due to water-flow velocities under waves, the sediment located on a slope may also become unstable under wave loading, 
resulting in slumping (Hooke, 1979). Vegetated soils are reinforced by the subsurface network of rhizomes and roots (Garofalo, 1980; Knutson, 1988; Van der Zee, 1992); a two- to threefold decrease in shear strength of soils on vegetated hill slopes has been demonstrated after clearcutting and removal of roots, resulting in a proportionally increased chance of slope failure (Gray, 1974; Waldron, 1977). The architecture and depth of the root system may be major determinants of the strength of a rooted bank (Mallik and Rasid, 1993). Although the difference between the depths of the root systems was not found to be significant, the present study did suggest that $S$. lacustris root systems are more easily uprooted by scour than those of $P$. australis. The latter species tended to show a more finely distributed root system that penetrated somewhat deeper into the soil. The presence of a root layer, acting as a protective mesh in which soil particles are captured, may have been the major cause of reduction of erosion by vegetation.

Wave forces, affected by bank slope and depth, interfered with the aboveground parts of the vegetation as well. Waves transmitted through the vegetation lose energy due to interference with vegetation and bottom surface. Although a $4 \mathrm{~m}$ wide band of vegetation can be regarded as a short distance, wave height measurements in the present study did show wave attenuation to occur. The large variability found in studies of wave extinction in emergent vegetation (USDA, 1974; Bonham, 1983; Bouter, 1991) could be largely attributed to differences in the experimental conditions, e.g. differences in flume geometry. Evaluation of wave extinction was further complicated by the altered soil profile and reflection patterns against the back wall of the flume. Computation of wave height reductions relative to the unplanted sections allowed wave attenuation to be compared for different time intervals and between the two species. The effect of seasonal development of the vegetation on wave height reduction was obvious. Summer measurements clearly showed wave attenuation, while no evidence of wave attenuation was found in the winter period and after the stands had been mown.

Indirect effects accompanying the mechanical influence of waves on the vegetation included distinct zones where organic matter and sediment were deposited or removed. Such zones may in the long term result in different growth patterns of helophytes over bank slopes.

In conclusion, there appears to be a strong reduction of the wave transmission as well as soil reinforcement due to the presence of vegetation, especially during the growing season. A stable vegetated bank may have a steeper slope compared to an unvegetated bank. The 'equilibrium' slope of a vegetated bank may change slightly as a result of increased wave attack, until the vegetation itself is damaged. Under the conditions of the present study, banks grown with $S$. lacustris appear to be more susceptible to high wave loading than banks with $P$. australis.

\section{Acknowledgements}

The study was part of a research project, initiated by the Dutch Department of Public Works, aimed at the formulation of guidelines for the use of vegetation as a means of bank protection. The research was supported financially by the Road and Hydraulic 
Engineering Division. We wish to thank F. de Groot (Delft Hydraulics) for his assistance during the study.

\section{References}

Bache, D.H. and Macaskill, I.A., 1981. Vegetation in coastal and stream-bank protection. Landscape Plann., 8: 363-385.

Bonham, A.J., 1983. The management of wave-spending vegetation as bank protection against boat wash. Landscape Plann., 10: 15-30.

Bouter, E.E., 1991. Wave damping by reed: an investigation in environmentally friendly bank protection. PIANC Bull., 75: 56-62.

Coops, H., Boeters, R. and Smit, H., 1991. Direct and indirect effects of wave attack on helophytes. Aquat. Bot., 41: 333-352.

Coops, H., Geilen, N. and Van der Velde, G., 1994. Distribution and growth of the helophyte species Phragmites australis and Scirpus lacustris in water depth gradients in relation to wave exposure. Aquat. Bot., 48: 273-284.

Denny, M.W., 1988. Biology and the Mechanics of the Wave-swept Environment. Princeton University Press, Princeton, NJ.

Garofalo, D., 1980. The influence of wetland vegetation on tidal stream channel migration and morphology. Estuaries, 3: 258-270.

Giroux, J.F. and Bédard, J., 1987. Factors influencing aboveground production of Scirpus-marshes in the St. Lawrence estuary, Québec, Canada. Aquat. Bot., 29: 195-204.

Gleason, M.L., Elmer, N.C., Pien, N.C. and Fisher, J.S., 1979. Effects of stem density upon sediment retention by salt marsh cord grass, Spartina alterniflora Loisel.. Estuaries, 2: 271-273.

Gray, D.H., 1974. Reinforcement and stabilization of soil by vegetation. J. Geotech. Eng. Div., 1: 696-699.

Hakanson, L. and Jansson, M., 1983. Principles of Lake Sedimentology. Springer, Berlin.

Hjulström, R., 1935. Studies on the morphological activity of rivers as illustrated by the River Fyris. Bull. Geol. Inst. Univ. Uppsala, 25: 221-527.

Hooke, J.M., 1979. An analysis of the processes of river bank erosion. J. Hydrol., 42: 39-62.

Huber, A. and Weiss, H.W., 1986. Wellenerosion am Rhein. Wasser Energ. Luft, 78: 205-211.

Knutson, P.L., 1988. Role of coastal marshes in energy dissipation and shore protection. In: D.D. Hook (Editor), The Ecology and Management of Wetlands, I. Croom Helm, London, pp. 161-175.

Mallik, A.U. and Rasid, H., 1993. Root-shoot characteristics of riparian plants in a flood control channel: implications for bank stabilization. Ecol. Eng., 2: 149-158.

Nanson, G.C., Von Krusenstiema, A., Bryant, E.A. and Renilson, M.R., 1994. Experimental measurements of river-bank erosion caused by boat-generated waves on the Gordon River. Tas. Regul. Riv., 9: 1-14.

Ranwell, D.S., 1964. Spartina salt marshes in Southern England, II. Role of seasonal pattern of sediment accretion. J. Ecol., 52: 79-94.

Spence, D.H.N., 1982. The zonation of freshwater plants. Adv. Ecol. Res., 12: 37-125.

Sukopp, H., Markstein, B. and Trepl, L., 1975. Rőhrichte unter tntensivem GroBstadteinfluss. Beitr. Naturkd. Forsch. Südwestdtsch., 34: 371-385.

Thome, C.R., 1990. Effects of vegetation on riverbank erosion and stability. In: J.B. Thornes (Editor), Vegetation and Erosion. Processes and Environments. Wiley, Chichester, pp. 125-144.

USDA, 1974. A guide for the design and layout of vegetative wave protection for earth dam embankments. U.S. Department of Agriculture, Soil Conservation Service, Technical Release No. 56, 28 pp.

Van der Zee, F.F., 1992. Botanische Samenstelling, Oecologie en Erosiebestendigheid van Rivierdijkvegetaties. Landbouwuniversiteit, Wageningen.

Waldron, L.J., 1977. The shear resistance of root-permeated homogeneous and stratified soil. J. Soil Sci. Soc. Am., 41: 843-849.

Weisner, S.E.B., 1987. The relation between wave exposure and distribution of emergent vegetation in a eutrophic lake. Freshwater Biol., 18: 537-544. 